This article was downloaded by: [Purdue University]

On: 21 January 2015, At: 14:44

Publisher: Routledge

Informa Ltd Registered in England and Wales Registered Number: 1072954

Registered office: Mortimer House, 37-41 Mortimer Street, London W1T

3J H, UK

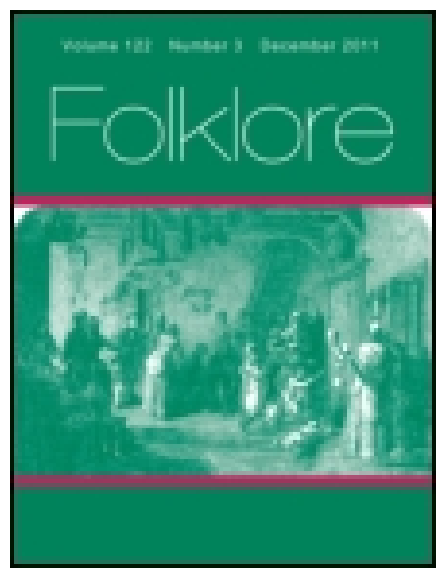

\title{
Folklore
}

Publication details, including instructions for authors and subscription information:

http:// www. tandfonline.com/loi/ rfol20

\section{A Survival of Tree-worship.}

Mary Lovett Cameron ${ }^{a}$

${ }^{\text {a }}$ Le Bagnore, Arcidosso, Prov. di Grosseto, Italy Published online: 06 Feb 2012.

To cite this article: Mary Lovett Cameron (1901) A Survival of Tree-worship., Folklore, 12:4, 455-456, DOI: 10.1080/0015587X.1901.9719651

To link to this article: http:// dx. doi.org/ 10.1080/0015587X.1901.9719651

\section{PLEASE SCROLL DOWN FOR ARTICLE}

Taylor \& Francis makes every effort to ensure the accuracy of all the information (the "Content") contained in the publications on our platform. However, Taylor \& Francis, our agents, and our licensors make no representations or warranties whatsoever as to the accuracy, completeness, or suitability for any purpose of the Content. Any opinions and views expressed in this publication are the opinions and views of the authors, and are not the views of or endorsed by Taylor \& Francis. The accuracy of the Content should not be relied upon and should be independently verified with primary sources of information. Taylor and Francis shall not be liable for any losses, actions, claims, proceedings, demands, costs, expenses, damages, and other liabilities whatsoever or howsoever caused arising directly or indirectly in connection with, in relation to or arising out of the use of the Content.

This article may be used for research, teaching, and private study purposes. Any substantial or systematic reproduction, redistribution, reselling, loan, sub-licensing, systematic supply, or distribution in any form to anyone is 
expressly forbidden. Terms $\&$ Conditions of access and use can be found at http://www.tandfonline.com/page/terms-and-conditions 


\section{The Fire Walk Ceremony in Tahiti. 455}

aken. Mr. Davey speaks of the "red-hot" stones, the flames leaping up between them, and the men who (in ordinary European dress, according to the photograph) turned them over with long poles, "so as to get the greatest heat uppermost"; but neither he nor any narrator previous to Mr. Langley explains whether or not he means the epithets "red-hot" and "white-hot" to apply to the upper surface of the topmost layer of stones at the moment of being trodden on I If not, then the witnesses are substantially agreed on this point. However, we are not dealing with conflicting accounts of the same event, but comparing the accounts of different events.

It is perhaps worth while to point out that in all Papa-Ita's performances of which we have particulars, the fire was made under a cairn of stones, and continued to burn during the exhibition, which must have added not a little to the exciting nature of the scene; while in other cases (New Zealand, Fiji) the pit, appears to have been lined with the stones and the firewood placed on them; what remained of it bcing removed (in Dr. Hocken's account) when they were sufficiently heated, after the manner of an old-fashioned bread-oven in England. $E_{D}$

\section{A Survival of Tree-worship. \\ (Communicated by Mr.J. G. Frazer.)}

In this little-visited corner of Tuscany I have come across what appears to me a curious survival of tree-worship, or rather, worship of the spirit of the woods. I am spending the summer in a little village on the edge of the great chestnut forests which cover Mount Amiata, an isolated mountain rising from the Maremma. All summer a movement has been going on; the peasants going away by twos and threes at night, and returning the next day, tired, but with a queer excited visionary look which was so marked that it excited my curiosity. 'At first they were unwilling to say much, only that they had been to visit a Madonna in an oak-tree; but as I have become well known they grow more communicative and enter into particulars. They walk to a certain valley, and there they 
assert that a lady (the Madonna, as they believe) appears in an oak-tree. They spend the night in a sort of ecstasy, of which they can tell little except that it leaves them "contentissimi." This has been going on all summer, and sometimes there are several thousand people on the spot. When one sees them going off after their hard day's work under the Italian sun, to take first a walk of four hours from here (many come from much further), and then to spend the whole night in this way, one cannot help feeling that some strong instinct or feeling must draw them.

The Church discourages the whole thing; the arch-priest of Santafiora goes so far as to assert that it is a work of the devil, but that would be his view of any survival of the worship of the wood-spirits. The people, though pious Catholics, will not be prevented from going to their oak-tree; they are persuaded it is the Madonna. The government, which dislikes any religious ferment among the people, has sent the carabinieri once, who tore off the offerings which the poor people had hung on the tree, and threw down and trampled on the candles they had fixed on it; but this has only irritated the believers. They threaten now to cut down the oak and post carabinieri on the spot, so the whole thing may soon be put down, and you may like to know about it while yet going on.

Peasants are not good hands at describing sensations; about their visions they can only say they see a strange light and the Madonna appears, and they see, or she tells them, wonderful beautiful things. It is all vague as to detail, but not as to the sentiment, or belief in the vision. Owing to its isolation, surrounded by the deadly Maremma, the people of this mountain are peculiarly primitive; but an electric tram is threatened, so one had better study them at once, as that will banish the spirits.

\section{Mary Lovett Camkron.}

Le Bagnore, Arcidosso, Prov. di Grosseto, Italy. I2th August, rgor. 